\title{
PENGGUNAAN KONTRASEPSI HORMONAL DAN OBESITAS PADA WANITA USIA SUBUR DI INDONESIA: ANALISIS DATA IFLS 5 TAHUN 2014
}

\section{The Use of Hormonal Contraceptive and Obesity among Reproductive-Age Women in Indonesia: 5th IFLS Data Analysis}

\author{
Yusri Kartika $^{1 *}$, Sudarto Ronoatmodjo ${ }^{2}$ \\ ${ }^{1}$ Freelance \\ ${ }^{2}$ Departemen Epidemiologi, Fakultas Kesehatan Masyarakat, Universitas Indonesia \\ *Email: ucchiekaayusri@ rocketmail.com
}

Naskah masuk 04 November 2019; review 19 November 2019; disetujui terbit 31 Desember 2019

\begin{abstract}
Background: Prevalence of obesity in adult females in Indonesia is 32,9\% in 2013. Hormonal contraceptives (pills, injections and implants) are widely used by reproductive-age women in Indonesia, and the prevalence is $45 \%$.

Objective: The aim of this study is to identify whether reproductive-age women who use hormonal contraceptives are at risk of developing obesity compared to WUS who do not use hormonal contraceptives.

Method: The design of this study is a cross sectional study using secondary data (5th Indonesia Family Life Survey, and the sample is reproductive-age women (15-49 years old) consisting of 6045 respondents. The variables of this study are obesity, hormonal contraceptive use, age, education, occupation, and duration of contraceptive use. Data were analysed by using Cox Regression.

Result: The results of bivariate analysis showed that hormonal contaceptive use, age, education, occupation, and duration of contraceptive use were associated with obesity among reproductive-age women and statistically significant $(P$-Value $<0,05)$. Multivariate analysis showed that hormonal contraceptive use did not increase the risk of obesity among reproductive-age women in Indonesia (PR 0.939; CI 95\% 0.869 - 1.013).

Conclusion: The use of hormonal contraception did not increase the risk of obesity among reproductive-age women.
\end{abstract}

Key words: Hormonal Contraception; Obesity; Reproductive Age-Women

\begin{abstract}
Abstrak
Latar belakang : Prevalensi obesitas pada perempuan dewasa di Indonesia sebesar 32,9 persen pada tahun 2013. Kontrasepsi hormonal (pil, suntikan dan implan) merupakan jenis kontrasepsi yang paling banyak digunakan oleh wanita usia subur (WUS) di Indonesia, dengan prevalensi sebesar $45 \%$.

Tujuan : untuk mengetahui apakah wanita usia subur (WUS) yang menggunakan kontrasepsi hormonal berisiko mengalami obesitas dibandingkan WUS yang tidak menggunakan kontrasepsi hormonal.

Metode : Desain penelitian ini adalah studi cross- sectional dengan menggunakan data sekunder IFLS 5 tahun 2014. Sampel adalah WUS (15-49 tahun) sebanyak 6.045 responden. Variabel dalam penilitian ini adalah obesitas pada WUS, penggunaan kontrasepsi hormonal, umur, pendidikan, pekerjaan, serta lama penggunaan kontrasepsi. Analisis data yang digunakan adalah Cox Regression.

Hasil : Hasil analisis bivariat menunjukkan bahwa variabel penggunaan kontrasepsi hormonal, umur, pendidikan dan status pekerjaan, serta lama penggunaan kontrasepsi berhubungan dengan obesitas pada WUS ( $p$-value $<0,05)$. Analisis multivariat menunjukkan bahwa penggunaan kontrasepsi hormonal tidak meningkatkan risiko obesitas secara bermakna pada WUS di Indonesia (PR 0,939; CI 95\% 0,869-1,013).
\end{abstract}

Kesimpulan: Penggunaan kontrasepsi hormonal tidak meningkatkan risiko WUS untuk mengalami obesitas.

Kata kunci: Kontrasepsi Hormonal; Obesitas; Wanita Usia Subur 


\section{PENDAHULUAN}

Obesitas merupakan akumulasi lemak yang abnormal atau berlebihan dan dapat menimbulkan risiko kesehatan. Obesitas menjadi faktor risiko utama bagi sejumlah penyakit tidak menular, seperti diabetes, penyakit jantung dan kanker, serta stroke dan masalah psikososial. Awalnya, obesitas dianggap masalah hanya pada negara - negara berpenghasilan tinggi. Namun, saat ini obesitas secara dramatis meningkat di negara - negara berpenghasilan rendah dan menengah, terutama di daerah perkotaan. ${ }^{1,2}$

Obesitas saat ini disebut sebagai The New World Syndrome, dimana obesitas di seluruh dunia meningkat hampir tiga kali lipat sejak 1975. Pada tahun 2016, lebih dari 1,9 miliar orang dewasa, mengalami kelebihan berat badan. Dari jumlah ini, lebih dari 650 juta orang mengalami obesitas, dimana 39 persen orang dewasa mengalami kelebihan berat badan dan 13 persen mengalami obesitas. Selain itu, sebagian besar penduduk dunia hidup di negaranegara dimana kelebihan berat badan dan obesitas membunuh lebih banyak orang daripada kekurangan berat badan. ${ }^{3}$ Obesitas pada perempuan dewasa di Indonesia meningkat berdasarkan hasil riset kesehatan tahun 2013. Dilaporkan pada tahun 2013, prevalensi obesitas perempuan dewasa 32,9 persen, naik 18,1 persen dari tahun 2007 $(13,9 \%)$ dan 17,5 persen dari tahun 2010 $(15,5 \%) .4,5$

Obesitas terjadi karena jumlah kalori yang masuk ke dalam tubuh melalui makanan lebih banyak dibandingkan jumlah kalori yang dibakar. Sehingga jika kondisi seperti ini terus berlangsung selama bertahun-tahun, akan mengakibatkan terjadinya penumpukan jaringan lemak yang berlebihan di dalam tubuh, sehingga terjadilah obesitas. Selain itu, keadaan lingkungan seseorang dan faktor keturunan juga berpengaruh terhadap timbulnya obesitas. Obatobatan dan beberapa hormon tertentu yang mempengaruhi nafsu makan seseorang dapat pula menimbulkan obesitas. ${ }^{1}$

Seseorang dikatakan mengalami obesitas bila akumulasi jumlah lemak di dalam tubuhnya lebih dari 20 persen di atas jumlah normal. ${ }^{6}$ Obesitas, selain dianggap sebagai gangguan estetika oleh sebagian orang, juga merupakan faktor risiko yang dapat dimodifikasi untuk penyakit tidak menular seperti penyakit jantung, diabetes, kanker, hipertensi, dan lain sebagainya. ${ }^{6,7}$

Penggunaan kontrasepsi hormonal pada Wanita Usia Subur (WUS) juga dianggap sebagai faktor yang menyebabkan kenaikan berat badan yang jika tidak dikontrol akan menyebabkan obesitas. Misalnya pada penggunaan pil, Tukiman menyatakan bahwa kontrasepsi pil dapat meningkatkan berat badan karena kandungan dari hormon estrogen dan progesteron yang terdapat pada kontrasepsi pil, dimana hormon estrogen menyebabkan retensi cairan dan oedema, sedangkan progesteron mempermudah penumpukan karbohidrat dan gula menjadi lemak dan merangsang nafsu makan serta menurunkan aktifitas fisik, akibatnya pemakaian kontrasepsi pil dapat menyebabkan kenaikan berat badan pada penggunanya. ${ }^{8}$

Sementara itu, penggunaan kontrasepsi di Indonesia meningkat dari 55,8 persen (Riskesdas 2010) menjadi 59,7 persen (Riskesdas 2013), untuk penggunaan kontrasepsi hormonal sebesar 51,9 persen, dan kontrasepsi non-hormonal sebesar 7,5 persen dan menurut metodenya 10,2 persen penggunaan metode kontrasepsi jangka panjang (MKJP), dan 49,1 persen non-MKJP. ${ }^{4}$ Oleh karena itu, penulis ingin mengetahui apakah WUS di Indonesia yang menggunakan kontrassepsi hormonal berisiko mengalami obesitas berdasarkan analisis data Indonesian Family Life Survey (IFLS) 5 tahun 2014.

\footnotetext{
* Corresponding author

(Email: ucchiekaayusri@rocketmail.com)
}

(C) National Institute of Health Research and Development ISSN: 2354-8762 (electronic); ISSN: 2087-703X (print) 


\section{METODE}

Desain penelitian yang digunakan dalam penelitian ini adalah Cross-sectional. Penelitian ini dilakukan dengan menggunakan data sekunder Indonesian Family Life Survey (IFLS) 5 versi 1.3 yang dirilis pada 12 April 2017 dari RAND dan Survey Meter yang pengambilan datanya dilakukan pada tahun 2014 - 2015 . IFLS adalah survei komprehensif longitudinal individual yang diambil dalam tingkat rumah tangga yang merupakan kerja sama dari lembaga penelitian dari Amerika Serikat $R A N D$ dan Survey Meter. Data IFLS di Indonesia mulai dikumpulkan pada tahun 1993 (IFLS 1) sampai dengan tahun 2014 (IFLS 5). Penarikan sampel dalam survei ini menggunakan stratified sampling yang dilakukan pada tingkat provinsi, kota dan desa. Sebanyak 13 dari 27 provinsi terpilih sebagai sampel yang mewakili 83 persen penduduk Indonesia. ${ }^{9}$ Analisis lanjut mengenai penelitian ini dilakukan di Depok pada bulan April hingga Juni 2018.

Populasi dalam penelitian ini adalah seluruh individu wanita yang ikut serta dalam IFLS 5 tahun 2014. Pada data IFLS 5, terdapat 16.204 rumah tangga yang menjadi sampel dan 50.148 individu yang diwawancarai. Populasi target yaitu seluruh wanita yang ikut serta pada IFLS 5 sebanyak 12.250 wanita. Kemudian setelah dilakukan cleaning data, dikeluarkan sebanyak 1.591 wanita dengan usia $<15$ tahun dan $>49$ tahun. Sehingga yang menjadi source population sebanyak 10.659 wanita. Kemudian dikeluarkan lagi sebanyak 4.602 wanita dari data penelitian karena memiliki hasil pengukuran yang tidak lengkap serta terdapat missing data. Sehingga jumlah wanita yang menjadi eligible population sebesar 6.057 wanita usia subur 15-49 tahun. Pada tahap pengolahan data selanjutnya, terdapat 12 wanita kembali memiliki missing data yaitu pada variabel penggunaan kontrasepsi. Sehingga total wanita yang menjadi sampel dalam penelitian ini sebesar 6.045 wanita yang memenuhi kriteria inklusi dan eksklusi penelitian ini.

Kriteria Inklusi pada penelitian ini yaitu semua wanita yang berusia $15-49$ tahun yang menjadi responden dalam pelaksanaan IFLS 5 tahun 2014 dan diukur berat badan dan tinggi badannya dan memiliki data yang lengkap pada seluruh variabel. Sedangkan kriteria eksklusi pada penelitian ini yaitu responden wanita usia
15 - 49 tahun yang tidak memiliki data pengukuran yang lengkap.

Variabel dalam penilitian ini adalah obesitas pada WUS, penggunaan kontrasepsi hormonal, umur, pendidikan, pekerjaan, serta lama penggunaan kontrasepsi. Variabel pekerjaan dikategorikan menjadi dua, yaitu tidak bekerja dan bekerja. Penentuan obesitas responden dilakukan dengan menghitung Indeks Massa Tubuh (IMT) setiap responden. Responden dikategorikan menggunakan kontrasepsi hormonal apabila responden menggunakan kontrasepsi pil atau suntikan (1 bulan, 2 bulan, 3 bulan) atau norplant/implant/susuk KB. Bila responden menggunakan metode/alat kontrasepsi berupa pantang berkala atau senggama terputus atau jamu tradisional atau pijat tradisional atau intravag atau kondom atau IUD/Alat Kontrasepsi Dalam Rahim (AKDR)/spiral atau tubektomi atau sterilisasi pria atau kondom wanita/femidom maka dikategorikan tidak menggunakan kontrasepsi hormonal. Umur responden dikategorikan menjadi dua, yaitu $<31$ tahun dan $\geq 31$ tahun yang diperoleh berdasarkan penghitungan nilai mean. Lama penggunaan kontrasepsi dikategorikan tidak berisiko jika lama penggunaan kontrasepsi responden $\leq 1$ tahun, dan dikategorikan berisiko jika lama penggunaan kontrasepsi responden $>1$ tahun. Pendidikan responden dikategorikan menjadi rendah dan tinggi. Pendidikan responden dikategorikan rendah apabila pendidikan terakhir responden pada saat penelitian adalah "Sekolah Dasar (SD)" atau "Sekolah Menengah Pertama (SMP) umum" atau "SMP kejuruan" atau "Kejar paket A" atau Kejar paket B" atau "sekolah untuk penyandang cacat (fisik/mental)" atau "Madrasah Ibtidaiyah (MI)" atau "Madrasah Tsanawiyah (MTs)" atau "taman kanak-kanak" atau "lainnya" dan dikategorikan tinggi apabila pendidikan terakhir responden pada saat penelitian adalah "Sekolah Menengah Atas (SMA) umum" atau "Sekolah Menengah Kejuruan (SMK)" atau "Madrasah Aliyah (MA)" atau "pesantren" atau "akademi (D1,D2,D3)" atau "kejar paket C" atau "Universitas Terbuka" atau "S1" atau "S2" atau "S3".

Analisis data dilakukan secara komputerisasi menggunakan software STATA versi 12 milik laboratorium komputer Fakultas Kesehatan Masyarakat Universitas Indonesia. Analisis dilakukan secara bertahap yaitu: analisis 
Univariat yang memberikan deskripsi karakteristik dari masing - masing variabel; analisis Bivariat dengan melakukan uji ChiSquare, besarnya hubungan antara kedua variabel yang diuji dinilai dengan menggunakan Prevalence Ratio (PR) dan 95\% Confidence Interval; analisis Multivariat dengan menggunakan analisis cox regression.

Pada penelitian ini tidak ada perlakuan atau intervensi terhadap sampel penelitian karena data yang digunakan merupakan data sekunder, yaitu data IFLS 5. Sebelum penelitian dilaksanakan, terlebih dahulu mengikuti kaji etik dari Komite Etik Penelitian Fakultas Kesehatan Masyarakat Universitas Indonesia, dan telah dinyatakan lulus kaji etik Nomor: 638/UN2.F10/PPM.00.02.2018 tanggal 22 Juni 2018. Sampel pada penelitian ini dijamin atas kerahasiaan data - datanya. Sehingga identitas sampel tidak akan dipublikasikan tanpa seizin sampel penelitian.

\section{HASIL}

Analisis data dilakukan terhadap 6.045 WUS yang eligible yang disajikan pada Tabel 1 sampai 3.

Tabel 1 menunjukkan bahwa sebanyak 59,24 persen WUS di Indonesia menggunakan kontrasepsi, dan di antara 3.581 WUS yang menggunakan kontrasepsi, 49,68 persen menggunakan kontrasepsi hormonal. Sedangkan jenis metode/alat kontrasepsi yang paling banyak digunakan oleh WUS di Indonesia adalah suntikan 3 bulan yaitu sebesar 29,42 persen dan jenis metode/alat kontrasepsi yang paling sedikit digunakan adalah obat tradisional, yaitu sebesar 0,06 persen.

Tabel 1 juga menunjukkan bahwa WUS yang mengalami obesitas di Indonesia adalah sebesar 43,44 persen. Selain itu, jumlah wanita yang berusia $\geq 31$ tahun yaitu sebesar 56,01 persen. Sebanyak 56,36 persen wanita berpendidikan rendah, dan sebesar 73,35 persen wanita tidak bekerja. Selain itu, sebesar 72,16 persen wanita telah menggunakan kontrasepsi $>1$ tahun.

Tabel 1 Distribusi Frekuensi Penggunaan Kontrasepsi, Jenis Kontrasepsi, Obesitas pada WUS, Umur, Pendidikan, Status Pekerjaan dan Lama Penggunaan Kontrasepsi

\begin{tabular}{lrr}
\hline \multicolumn{1}{c}{ Variabel } & $\begin{array}{c}\text { Jumlah } \\
(\mathbf{n})\end{array}$ & $\begin{array}{c}\text { Persentase } \\
(\%)\end{array}$ \\
\hline Penggunaan kontrasepsi & & \\
Ya & 3.581 & 59,24 \\
Tidak & 2.464 & 40,76 \\
\hline Jenis Kontrasepsi & & \\
Pil & 690 & 11,41 \\
Suntikan 1 bulan & 314 & 5,19 \\
Suntikan 2 bulan & 17 & 0,28 \\
Suntikan 3 bulan & 1.779 & 29,42 \\
Kondom & 89 & 1,47 \\
IUD/AKDR/Spiral & 256 & 4,23 \\
Norplant/Implant/susuk KB & 203 & 3,35 \\
Sterilisasi wanita & 159 & 2,63 \\
Sterilisasi pria & 6 & 0,09 \\
Metode kalendar & 45 & 0,74 \\
Sanggama terputus & 13 & 0,21 \\
Obat tradisional & 2 & 0,03 \\
Lainnya & 8 & 0,13 \\
\hline Obesitas & & \\
Ya & 2.626 & 43,44 \\
Tidak & 3.419 & 56,56 \\
\hline Penggunaan Kontrasepsi hormonal & & \\
Ya & 3.003 & 49,68 \\
Tidak & 3.042 & 50,32 \\
\hline Umur & & \\
Z31 tahun & 3.386 & 56,01 \\
<31 tahun & 2.659 & 43,99 \\
& & \\
\hline
\end{tabular}




\begin{tabular}{lcr}
\hline \multicolumn{1}{c}{ Variabel } & $\begin{array}{c}\text { Jumlah } \\
(\mathbf{n})\end{array}$ & $\begin{array}{c}\text { Persentase } \\
(\boldsymbol{\%})\end{array}$ \\
\hline Pendidikan & & \\
$\quad$ Rendah & 3.407 & 56,36 \\
$\quad$ Tinggi & 2.638 & 43,64 \\
\hline $\begin{array}{l}\text { Status Pekerjaan } \\
\quad \text { Tidak bekerja }\end{array}$ & 4.434 & 73,35 \\
$\quad$ Bekerja & 1.611 & 26,65 \\
\hline Lama penggunaan kontrasepsi & & \\
$\quad>1$ tahun & 4.362 & 72,16 \\
$\quad \leq 1$ tahun & 1.683 & 27,84 \\
\hline Total & 6.045 & 100.00 \\
\hline
\end{tabular}

Tabel 2 menunjukkan hasil penelitian pada tahap analisis bivariat hubungan antara penggunaan kontrasepsi hormonal dan variabel kovariat (umur, pendidikan, status pekerjaan, dan lama penggunaan kontrasepsi) dengan obesitas, dari hasil analisis hubungan antara penggunaan kontrasepsi hormonal dengan obesitas diketahui bahwa wanita yang menggunakan kontrasepsi hormonal sebesar 42,06 persen mengalami obesitas. Artinya persentase kejadian obesitas pada wanita yang menggunakan kontrasepsi hormonal lebih kecil persentasenya daripada yang tidak menggunakan kontrasepsi hormonal, dengan nilai prevalens rasio sebesar 0,937 dan nilai $C I$ $95 \%(0,886$ - 0,994). Sehingga hubungan antara penggunaan kontrasepsi dengan obesitas bermakna secara statistik.

Tabel 2 menyajikan hasil uji chi square variabel bebas terhadap obesitas. Wanita dengan umur 31 tahun $\mathrm{ke}$ atas $(51,68 \%)$ mempunyai persentase obesitas lebih besar dibandingkan dengan usia kurang dari 31 tahun $(32,94 \%)$, dengan nilai prevalensi rasio sebesar 1,569. Artinya responden dengan kategori umur 31 tahun ke atas berisiko untuk mengalami obesitas sebesar 1,569 kali dibandingkan responden dengan kategori umur kurang dari 31 tahun, pada CI 95\% $(1,472-1,671)$.

Wanita usia subur dengan pendidikan rendah dan mengalami obesitas sebesar 44,88 persen mempunyai persentase obesitas lebih besar dibandingkan dengan responden dengan pendidikan tinggi $(41,58 \%)$ dan dengan nilai prevalensi rasio sebesar 1,079. Artinya responden dengan kategori pendidikan rendah berisiko untuk mengalami obesitas sebesar 1,079 kali dibandingkan responden dengan kategori pendidikan tinggi, dengan nilai CI 95\% $(1,017-1,144)$ (Tabel 2).

Tabel 2 juga menunjukkan hubungan antara status pekerjaan dengan obesitas, dengan nilai prevalensi rasio sebesar 0,912 dan CI 95\% $(0,857$ - 0,971). Secara statistik, status pekerjaan dan obesitas memiliki hubungan yang bermakna.

Hasil uji statistik (Tabel 2) juga menunjukkan adanya hubungan antara lama penggunaan kontrasepsi dengan obesitas, yang menunjukkan nilai prevalensi rasio sebesar 1,175 , artinya lama penggunaan $\mathrm{KB}>1$ tahun berisiko mengalami obesitas sebesar 1,175 kali dibandingkan WUS dengan lama penggunaan $\leq 1$ tahun, dan nilai CI 95\% $(1,097-1,258)$.

Pada analisis multivariat, dari semua variabel yang potensial confounder, tidak ditemukan variabel yang menjadi confounding. Model akhir dari analisis multivariat hubungan antara penggunaan kontrasepsi hormonal dengan obesitas pada WUS di Indonesia (Tabel 3) menjelaskan bahwa penggunaan kontrasepsi hormonal bukan merupakan faktor risiko atau tidak berhubungan dengan obesitas pada WUS di Indonesia, dengan P-Value 0,105 (CI 95\% 0,869

$1,013)$. 
Tabel 2. Analisis Hubungan Variabel Independen dan Kovariat dengan Obesitas pada WUS di Indonesia Berdasarkan Data IFLS 5 Tahun 2014

\begin{tabular}{|c|c|c|c|c|c|c|c|c|}
\hline \multirow{3}{*}{ Variabel } & \multicolumn{4}{|c|}{ Obesitas } & \multirow{2}{*}{\multicolumn{2}{|c|}{ Total }} & \multirow{3}{*}{$\begin{array}{c}P \text { - } \\
\text { value }\end{array}$} & \multirow{3}{*}{$\begin{array}{c}P R * * \\
(95 \% C I)\end{array}$} \\
\hline & \multicolumn{2}{|c|}{ Ya } & \multicolumn{2}{|c|}{ Tidak } & & & & \\
\hline & $\mathbf{n}$ & $\%$ & $\mathbf{n}$ & $\%$ & $\mathbf{n}$ & $\%$ & & \\
\hline \multicolumn{9}{|c|}{ Penggunaan Kontrasepsi Hormonal } \\
\hline Ya & 1.263 & 42,06 & 1.740 & 57,94 & 3.003 & 100 & \multirow{2}{*}{$0,0311^{*}$} & 0,937 \\
\hline Tidak & 1.363 & 44,81 & 1.679 & 55,19 & 3.042 & 100 & & $(0,886-0,994)$ \\
\hline \multicolumn{9}{|l|}{ Umur } \\
\hline$\geq 31$ tahun & 1.750 & 51,68 & 1.636 & 48,32 & 3.386 & 100 & \multirow{2}{*}{$0,0001^{*}$} & 1,569 \\
\hline$<31$ tahun & 876 & 32,94 & 1.783 & 67,06 & 2.659 & 100 & & $(1,472-1,671)$ \\
\hline \multicolumn{9}{|l|}{ Pendidikan } \\
\hline Rendah & 1.529 & 44,88 & 1.878 & 55,12 & 3.407 & 100 & \multirow{3}{*}{$0,0104^{*}$} & 1,079 \\
\hline Tinggi & 1.097 & 41,58 & 1.541 & 58,42 & 2.638 & 100 & & $(1,017-1,144)$ \\
\hline \multicolumn{8}{|c|}{ Status Pekerjaan } & \\
\hline Tidak bekerja & 1.878 & 42,35 & 2.556 & 57,65 & 4.434 & 100 & \multirow{2}{*}{$0,0047^{*}$} & 0,912 \\
\hline Bekerja & 748 & 46,43 & 863 & 53,57 & 1.611 & 100 & & $(0,857-0,971)$ \\
\hline \multicolumn{9}{|c|}{ Lama Penggunaan Kontrasepsi } \\
\hline$>1$ tahun & 1.977 & 45,32 & 2.385 & 54,68 & 4.362 & 100 & \multirow{2}{*}{$0,0001^{*}$} & 1,175 \\
\hline$\leq 1$ tahun & 649 & 38,56 & 1.034 & 61,44 & 1.683 & 100 & & $(1,097-1,258)$ \\
\hline
\end{tabular}

Tabel 3. Model Akhir Analisis Multivariat Hubungan Penggunaan Kontrasepsi Hormonal dengan Obesitas pada WUS di Indonesia Berdasarkan Data IFLS 5 Tahun 2014

\begin{tabular}{lccclc}
\hline \multicolumn{1}{c}{ Variabel } & Koef & PR & SE & P-Value & CI 95\% \\
\hline $\begin{array}{l}\text { Penggunaan Kontrasepsi } \\
\text { Hormonal }\end{array}$ & $-0,063$ & 0,939 & 0,036 & 0,105 & $0,869-1,013$ \\
\hline
\end{tabular}

\section{PEMBAHASAN}

Hasil penelitian ini menyatakan bahwa persentase obesitas pada WUS sebesar 43,44 persen. Temuan ini jauh lebih besar bila dibandingkan dengan data WHO yang menyebutkan prevalensi obesitas pada orang dewasa yang berusia 18 tahun ke atas yang mengalami obesitas sebesar 13 persen. Di Indonesia sendiri, berdasarkan hasil Riskesdas tahun 2013 dilaporkan prevalensi obesitas pada perempuan dewasa adalah sebesar 32,9 persen. $^{4}$

Hasil penelitian menunjukkan bahwa sebanyak 59,24 persen WUS di Indonesia menggunakan alat/metode kontrasepsi, kemudian sebesar 49,68 persen menggunakan kontrasepsi hormonal. Data hasil Riskesdas tahun 2013 melaporkan bahwa proporsi penggunaan kontrasepsi hormonal di Indonesia sebesar 51,9 persen. ${ }^{4}$ Sedangkan data hasil survei RPJMN tahun 2017 yang dilakukan oleh BKKBN menunjukkan bahwa penggunaan kontrasepsi hormonal pada WUS sebesar 38,2 persen, dengan penggunaan susuk $\mathrm{KB}$ sebesar 2,38 persen, suntikan 24,26 persen dan pil KB 9,42 persen. ${ }^{10}$ selain itu, berdasarkan laporan Survei Demografi dan Kesehatan Indonesia (SDKI) tahun 2017 diketahui bahwa prevalensi penggunaan kontrasepsi hormonal pada WUS sebesar 45 persen. ${ }^{11}$ Tingginya penggunaan kontrasepsi hormonal, khususnya suntikan dikarenakan kontrasepsi ini dianggap praktis, mudah, dan murah. ${ }^{12}$

Dalam penelitian ini, penggunaan kontrasepsi hormonal tidak berpengaruh terhadap obesitas pada WUS (P-Value: 0,105; 95\% CI: 0,869 1,013). Hasil penelitian ini sejalan dengan penelitian sebelumnya yang mengatakan bahwa tidak terdapat pengaruh yang signifikan antara paparan Depo Progestin terhadap berat badan dengan $\quad P$-Value $\quad 0,479 .{ }^{13}$ 
Penelitian lain yang dilakukan oleh Hasan di Manado, diperoleh hasil analisis chi-square $P=0,585>\alpha=0,05$. Hasil penelitian tersebut juga menunjukkan bahwa tidak terdapat hubungan antara penggunaan kontrasepsi dengan obesitas pada wanita usia subur (WUS) ${ }^{14}$ Sebuah systematic review terhadap 22 studi, menyatakan bahwa dari 22 studi tersebut menunjukkan terbatasnya bukti yang mengatakan bahwa penggunaan pil KB menyebabkan obesitas. Walaupun terjadi penambahan berat badan, rata - rata hanya bertambah kurang dari $2 \mathrm{~kg}$ pada 6 sampai pada 12 bulan penggunaan pada sebagian besar penelitian yang direview. ${ }^{15}$

Hal ini berbeda dengan hasil penelitian Pascoal yang menyatakan bahwa wanita yang menggunakan kontrasepsi hormonal (suntikan $\mathrm{KB}$, pil $\mathrm{KB}$ dan implant) mempunyai risiko kemungkinan 3 kali lebih besar untuk mengalami obesitas dibandingkan wanita yang menggunakan kontrasepsi non hormonal. ${ }^{16}$ Penelitian sebelumnya juga mengatakan bahwa penggunaan kontrasepsi hormonal dapat meningkatkan berat badan hingga terjadinya obesitas. Kontrasepsi hormonal berhubungan dengan perubahan dalam metabolisme beberapa zat gizi yang dapat menyebabkan terjadinya peningkatan berat badan. Hormon estrogen menyebabkan retensi cairan dan oedema, sedangkan progesterone mempermudah penumpukan karbohidrat dan gula menjadi lemak dan dapat merangsang pusat pengendalian nafsu makan di hipotalamus sehingga menyebabkan terjadinya peningkatan nafsu makan. ${ }^{8,17}$

Selain itu, penelitian yang dilakukan oleh Bakry pada hewan uji mengenai efek DMPA (DepoMedroxyProgesterone Acetate) pada berat badan menyatakan bahwa salah satu pemicu terjadinya peningkatan berat badan adalah karena menurunnya kadar hormon estrogen setelah menggunakan kontrasepsi DMPA. ${ }^{18}$ Sehingga wanita yang menggunakan Depo Progestin dimungkinkan mengalami penurunan kadar hormon leptin serum yang dipicu oleh kadar estrogen yang turun. Kemudian kadar hormon leptin yang rendah akan menekan sinyal kenyang yang berakibat pada terjadinya peningkatan nafsu makan. Estrogen sebagai hormon seks memiliki efek pada metabolisme jaringan adiposit. Penurunan estrogen endogen berkorelasi dengan munculnya perubahan distribusi lemak tubuh, termasuk peningkatan total massa lemak dan obesitas sentral. ${ }^{19}$

Penelitian sebelumnya melaporkan bahwa terdapat beberapa faktor yang berpengaruh terhadap obesitas, diantaranya umur, pendidikan, pekerjaan, dan lama penggunaan kontrasepsi. Penelitian yang dilakukan oleh Grundy menyatakan bahwa ada hubungan yang bermakna antara umur dengan kejadian obesitas. ${ }^{20}$ Selain itu, meskipun ada perbedaan dalam penetapan cut off point umur, hasil peneltian lain menyebutkan bahwa proporsi status gizi obesitas pada subjek umur $\geq 40$ tahun lebih banyak meskipun memiliki nilai $P>$ $0,05 .{ }^{21}$

Pendidikan seseorang juga berpengaruh dalam terjadinya obesitas, menurut Contento, seseorang dengan tingkat pendidikan yang lebih tinggi akan lebih baik dalam menerima, memproses, menginterpretasikan, dan menggunakan informasi, khususnya pengetahuan gizi, responden yang berpendidikan lebih tinggi akan memiliki pengetahuan gizi yang lebih tinggi karena memiliki pengalaman dan akses informasi yang lebih banyak sehingga dapat memiliki sikap dan praktik gizi yang lebih baik khususnya dalam hal perilaku konsumsi pangan dan aktivitas fisik yang erat kaitannya dengan kegemukan. ${ }^{22}$ Hal ini didukung dengan penelitian Cohen et al. yang menunjukkan bahwa lulusan perguruan tinggi berisiko lebih rendah untuk mengalami obesitas dibandingkan lulusan sekolah dasar $(\mathrm{RR}=0,96){ }^{23}$

Dalam penelitian ini, status pekerjaan dan obesitas memiliki hubungan yang bermakna secara statistik, karena pada dasarnya, jenis pekerjaan yang dilakukan sehari - hari dapat mempengaruhi gaya hidup seseorang. Pekerjaan berpotensi menjadi faktor risiko obesitas terkait faktor sosial-ekonomi lainnya dan faktor perilaku seperti aktivitas fisik dan waktu sedentary. Pekerja kategori profesional lebih cenderung mengalami obesitas dari pada pekerja kategori buruh $(\mathrm{OR}=1,31 ; 95 \% \mathrm{CI}=1,19$ - 1,44). ${ }^{24}$ Sedangkan pada temuan lain menunjukkan bahwa ibu rumah tangga juga berisiko mengalami obesitas, hal ini dikarenakan mereka lebih banyak memiliki waktu luang sehingga aktivitas fisiknya menjadi berkurang. ${ }^{25}$ 
Sebagaimana diketahui bahwa penggunaan kontrasepsi hormonal memiliki efek samping yakni peningkatan berat badan yang menyebabkan obesitas. Kejadian obesitas juga dipengaruhi oleh lamanya seorang akseptor menggunakan suatu alat atau cara kontrasepsi hormonal. Berdasarkan penelitian yang dilakukan oleh Erawati pada akseptor KB suntik menunjukkan bahwa proporsi akseptor dengan lama penggunaan KB suntik $>1$ tahun mengalami peningkatan berat badan sebesar 62,1 persen. ${ }^{26}$ Penelitian lain juga menunjukkan hasil bahwa wanita yang menggunakan DMPA memiliki peningkatan yang signifikan dalam semua ukuran kegemukan dibandingkan wanita yang tidak menggunakan metode kontrasepsi hormonal (P 0,03). Penelitian yang dilakukan Clark dkk yakni pengamatan berat badan dari pengguna DMPA, menunjukkan peningkatan $6,1 \mathrm{~kg}$ setelah 30 bulan pengamatan $(8,8 \%)$. Massa lemak juga meningkat dari rata-rata 25,3 $\mathrm{kg}$ pada awal pengamatan menjadi $31,4 \mathrm{~kg}$, dengan peningkatan $6,1 \mathrm{~kg}(23,6 \%)$ pada pengguna DMPA. ${ }^{27}$

Dengan demikian hasil penelitian ini memberikan indikasi yang baik untuk program $\mathrm{KB}$ bahwa alat kontrasepsi tidak mempunyai efek samping obesitas. Adanya hasil penelitian lain yang menunjukkan adanya hubungan dengan obesitas dimungkinkan adanya faktor lain penyebab obesitas.

Selain itu, para wanita yang ikut serta dalam penelitian ini mungkin telah mendapatkan edukasi dan informasi yang komprehensif dari tenaga kesehatan mengenai pemilihan alat kontrasepsi yang sesuai sebelum memutuskan untuk menggunakan salah satu alat kontrasepsi dan segera menghentikan penggunaan jika memiliki keluhan peningkatan berat badan yang signifikan. Sehingga hasil penelitian ini menunjukkan tidak adanya hubungan antara penggunaan kontrasepsi hormonal dengan obesitas.

\section{KESIMPULAN}

Penggunaan kontrasepsi hormonal bukan merupakan faktor risiko atau tidak berhubungan dengan obesitas pada WUS di Indonesia (PR 0,939; $95 \%$ CI: $0,869-1,013)$.

\section{SARAN}

Wanita usia subur tidak perlu mencemaskan akan mengalami obesitas jika menggunakan kontrasepsi hormonal. Namun, perlu melakukan konsultasi ke tenaga kesehatan mengenai pilihan alat kontrasepsi yang tepat. Selain itu, untuk mencegah terjadinya obesitas, perlu mengatur pola makan dan melakukan aktivitas fisik.

\section{UCAPAN TERIMA KASIH}

Penelitian ini dapat terlaksana dengan baik, tidak terlepas dari bantuan dan dukungan dari berbagai pihak. Peneliti mengucapkan terima kasih kepada pemilik data IFLS yaitu RAND dan Survey Meter, Lembaga Pengelola Dana Pendidikan (LPDP), dan dosen Fakultas Kesehatan Masyarakat Universitas Indonesia.

\section{DAFTAR PUSTAKA}

1. Husnah H. Tatalaksana Obesitas. J Kedokt Syiah Kuala [Internet]. 2012 [cited 2018 Apr 10];12(2):99-104. Available from: http://www.jurnal.unsyiah.ac.id/JKS/articl e/viewFile/3506/3259

2. WHO. WHO | Obesity [Internet]. WHO. World Health Organization; 2014 [cited 2018 Apr 10]. Available from: http://www.who.int/topics/obesity/en/

3. WHO. WHO | Obesity and overweight [Internet]. WHO. World Health Organization; 2018 [cited 2018 Apr 6]. Available from: http://www.who.int/mediacentre/factsheets /fs311/en/

4. Kementerian Kesehatan. Riset Kesehatan Dasar 2013 [Internet]. 2013 [cited 2018 Feb 15]. Available from: http://labmandat.litbang.depkes.go.id/imag es/download/laporan/RKD/2013/Laporan_ riskesdas_2013_final.pdf

5. Kementerian Kesehatan. Riset Kesehatan Dasar (RISKESDAS) 2010 [Internet]. Jakarta; 2010 [cited 2019 Dec 27]. Available from: http://kesga.kemkes.go.id/images/pedoma n/Riskesdas 2010 Nasional.pdf

6. Wiramihardja KK. obesitas dan Penanggulangannya. Yurdani S, Kusmawan I, editors. Bandung: Granada; 
2004.

7. Webber L, Kilpi F, Marsh T, Rtveladze K, Brown M, McPherson K. High rates of obesity and non-communicable diseases predicted across Latin America. PLoS One [Internet]. 2012 [cited 2018 Jun 4];7(8):e39589. Available from: http://www.ncbi.nlm.nih.gov/pubmed/229 12663

8. Rayma GA, Mahdiyah D, Mahpolah M. Hubungan Penggunaan Kontrasepsi Pil dengan Berat Badan pada Akseptor KB di Puskesmas Teluk Tiram Banjarmasin [Internet]. Akademi Kebidanan Sari Mulia Banjarmasin; 2016 [cited 2018 Apr 4]. Available from: http://repository.stikessarimulia.ac.id/wpcontent/uploads/2017/08/Getha-Annisarayma-S.13.1382.pdf

9. Strauss J, Witoelar F, Sikoki B. User's Guide for the Indonesia Family Life Survey, Wave 5: Volume 2 [Internet]. Santa Monica: RAND Corporation; 2016 [cited 2018 Jun 3]. (WR-1143/2NIA/NICHD ). Available from: http://www.rand.org/pubs/working_papers /WR1143z2.html

10. BKKBN. Survei Indikator Kinerja Program KKBPK RPJMN 2017. Jakarta; 2017.

11. BPS, BKKBN, Kemenkes. Survei Demografi dan Kesehatan Indonesia 2017 (Laporan Indikator Utama) [Internet]. Jaka; 2018. Available from: http://demografi.bps.go.id/phpfiletree/sdki/ BahanAjarSDKI2007/Lainnya/Publikasi SDKI 2002-2003/RingkasanSDKI0203.pdf

12. Rahmawati NMA, Andrajati R, Supardi S. Perbandingan Penggunaan Kontrasepsi Suntik Zat Tunggal dan Kombinasinya terhadap Kejadian Reaksi Obat yang Tidak Dikehendaki di Satu Bidan Praktek Kota Depok. J Kefarmasian Indones [Internet]. 2017 [cited 2018 Jun 4];7(1):46-54. Available from: https://media.neliti.com/media/publication s/105030-ID-perbandingan-penggunaankontrasepsi-sunt.pdf

13. Wahyuni ES. Efek Paparan Depo Progestin Terhadap Hormon Pengatur Nafsu Makan (Leptin) dan Berat Badan pada Tikus Putih Betina. J Kebidanan Indones [Internet]. 2016 [cited 2018 Jun 5];7(1):27-37. Available from: http://jurnal.stikesmus.ac.id/index.php/JKe bIn/article/view/46

14. Hasan M, Mayulu N, Kawengian S. Hubungan Penggunaan Kontrasepsi Hormonal Dengan Obesitas Pada Wanita Usia Subur (Wus) Di Puskesmas Wawonasa Kecamatan Singkil Manado. J e-Biomedik. 2013;1(2):946-50.

15. Lopez LM, Ramesh S, Chen M, Edelman A, Otterness C, Trussell J, et al. Progestinonly contraceptives: effects on weight. PMC [Internet]. 2017 [cited 2018 Apr 5]; Available from: https://www.ncbi.nlm.nih.gov/pmc/articles /PMC5034734/pdf/nihms816372.pdf

16. Pascoal M, Bongakaraeng B, Mamuaya $\mathrm{T}$. Penggunaan Kontrasepsi Hormonal dan Terjadinya Obesitas pada Wanita Pengguna Kontrasepsi di Kota Bitung. JIK [Internet]. 2011 [cited 2018 Apr 23];6:97110. Available from: https://www.ejurnal.poltekkesmanado.ac.i d/index.php/inf/article/view/182/159

17. Pratiwi D, Syahredi S, Erkadius E. Hubungan Antara Penggunaan Kontrasepsi Hormonal Suntik DMPA dengan Peningkatan Berat Badan di Puskesmas Lapai Kota Padang. J Kesehat Andalas [Internet]. 2014 Sep 1 [cited 2018 Apr 20];3(3). Available from: http://jurnal.fk.unand.ac.id/index.php/jka/a rticle/view/130

18. Bakry S, Abdullah A. Effect Of Depot Medroxyprogesterone (DMPA) On Body Weight And Serum Lipid Profile In Adult Female Rats. Egypt J Biochem Mol Biol [Internet]. 2009 Jun 3 [cited 2018 Jun 5];27(1). Available from: http://www.ajol.info/index.php/ejbmb/artic le/view/43181

19. Yi KW, Shin J-H, Seo HS, Lee JK, Oh MJ, Kim T, et al. Role of Estrogen Receptor$\alpha$ and $-\beta$ in Regulating Leptin Expression in 3T3-L1 Adipocytes. Obesity [Internet]. 2008 Nov [cited 2018 Jun 5];16(11):23939. Available from: http://doi.wiley.com/10.1038/oby.2008.38 9

20. Grundy SM. Multifactorial Causation of 
Obesity : Implications for Prevention. Am J Clin Nutr. 1998;67(3):563S-572S.

21. Nurzakiah N, Achadi E, Sartika RAD. Faktor Risiko Obesitas pada Orang Dewasa Urban dan Rural. J Kesehat Masy Nas [Internet]. 2010 [cited 2018 Jun 4];5:29-34. Available from: https://media.neliti.com/media/publication s/39465-ID-faktor-risiko-obesitas-padaorang-dewasa-urban-dan-rural.pdf

22. Diana R, Yuliana I, Yasmin G, Hardinsyah D. Faktor Risiko Kegemukan pada Wanita dewasa Indonesia (Risk Factors of Overweight among Indonesian Women). J Gizi dan Pangan [Internet]. 2013 [cited 2018 Apr 24];8:1-8. Available from: http://jesl.journal.ipb.ac.id/index.php/jgizi pangan/article/viewFile/7226/5647

23. Cohen AK, Rehkopf DH, Deardorff J, Abrams B. Education and obesity at age 40 among American adults. Soc Sci Med [Internet]. 2013 Feb 1 [cited 2018 Apr 24];78:34-41. Available from: https://www.sciencedirect.com/science/arti cle/pii/S0277953612007836

24. Rahmida YP, Hasnbasri M. Hubungan antara jenis pekerjaan dengan Obesitas pada Penduduk Dewasa di daerah Perkotaan di Indonesia (Analisis Data Indonesian Life Survey Gelombang Ke-5) [Internet]. Universitas Gadjah Mada; 2016 [cited 2018 Apr 24]. Available from: http://etd.repository.ugm.ac.id/index.php? mod=penelitian_detail\&sub=PenelitianDet ail\&act=view\&typ=html\&buku_id=10302 3\&obyek_id=4

25. Apriaty L. Faktor Risiko Obesitas Ibu Rumah Tangga di Kelurahan Bendungan Kecamatan Gajahmungkur Kota Semarang [Internet]. Universitas Diponegoro; 2015 [cited 2018 Apr 24]. Available from: http://eprints.undip.ac.id/47071/1/747_LI NDA_APRIATY.pdf

26. Erawati D. Hubungan Lama Pemakaian Kontrasepsi Suntik dengan peningkatan berat Badan pada Akseptor Suntik Depo medroksi progesteron Asetat di bidan praktik Mandiri (BPM) Sugiyati kajoran Magelang [Internet]. Sekolah Tinggi Ilmu Kesehatan 'Aisyiyah Yogyakarta; 2014 [cited 2018 Apr 4]. Available from: http://digilib.unisayogya.ac.id/1871/1/Nas kah publikasi.pdf

27. Clark M, Dillon J, Sowers M, Nichols S. Weight, fat mass, and central distribution of fat increase when women use depotmedroxyprogesterone acetate for contraception. Int J Obes [Internet]. 2005 [cited 2018 Apr 24];29:1252-8. Available from:

https://www.nature.com/articles/0803023. pdf 